\title{
Выбор оптимальной структуры фоточувствительной гибридной сборки на охлаждаемом пьедестале криостата
}

\author{
П.С. Загубисало, А.Р. Новоселов \\ Филиал ИФП СО РАН «КТИПМ», Новосибирск, 630090, проспект Академика Лаврентьева, 2/1 \\ тел:+ 7 (383) 330-97-49, внут. номер 365, эл. nочта: peter.zagubisalo@gmail.com
}

DOI 10.34077/RCSP2021-151

Проведено сравнение известных способов фиксации фоточувствительной гибридной сборки на охлаждаемом пьедестале криостата. Оно осуществлялось на модели сборки, состоящей из пластин: GaAs / In / Si / GaAs (опциональный компенсационный слой). Способы фиксации: закрепление сборки, позволяющее свободно изгибаться при охлаждении, жесткое крепление сборки на сапфировом растре со стороны кремниевой микросхемы. Варьирование толщин в рамках сравниваемых способов фиксации, позволило выбрать оптимальную конструкцию крепления гибридной сборки в охлаждаемом криостате. Исследование проводилось с помощью радиально-симметричной модели, в которой напряжения при охлаждении моделировались методом конечных элементов. Диаметр всех слоёв равнялся 10 мм. Толщины слоёв GaAs и кремния варьировались от 50 мкм до 700 мкм, компенсационного слоя GaAs - от 0 мкм до 700 мкм. Толщина слоя сапфира бралась много больше исследованных толщин GaAs и кремния. Индиевые столбы в реальности высотой 5 мкм, диаметром 15 мкм и с периодом квадратной ячейки 30 мкм были моделированы индиевыми кольцами в радиальносимметричной модели - так же с высотой 5 мкм, толщиной 15 мкм и периодом между центрами колец 30 мкм. При охлаждении с 293.15 К до 77 К максимальные напряжения (по Мизесу) в индии регистрировались в кольце наибольшего диаметра на одном из концов границы крепления кольца к другим слоям (в 2D срезе радиально-симметричной модели) - это вызывается локальным сдвигом слоев GaAs и кремния друг относительно друга из-за теплового сжатия. Сравнение целевых напряжений (максимальных напряжений в индии) показало:

Наименьшее целевое напряжение возникает в случае, когда сборка утонена до 50 мкм GaAs и 50 мкм Si без компенсационного слоя GaAs (свободно изгибается) - 427 МПа. Против 888 МПа при толщинах 420 мкм GaAs и 420 мкм кремния с креплением на сапфировом растре (без компенсационного слоя GaAs). Наилучшим вариантом для случая крепления сборки на сапфировом растре получился вариант с компенсационным слоем GaAs (толщиной 100 мкм) при утонении толщин GaAs и кремния до 50 мкм. При этом, целевое напряжение в индии составило 600 МПа. Изменение целевых напряжений в районе минимумов показаны на Рис. 1. Стоит отметить, что порядок величин напряжений в слоях индия и GaAs совпадает с порядком напряжений в слое GaAs из работы [1]: 236 MPa.

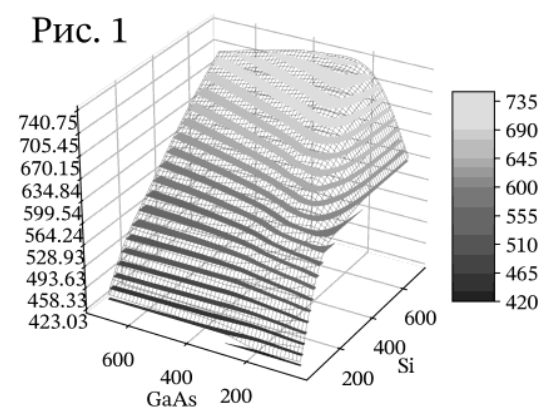

Своб., GaAs (комп.) $=0$

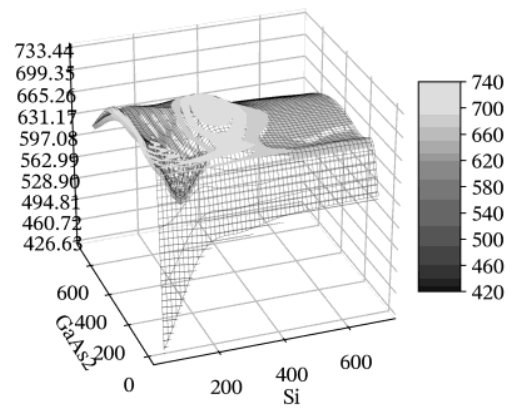

Своб., GaAs = 50 мкм

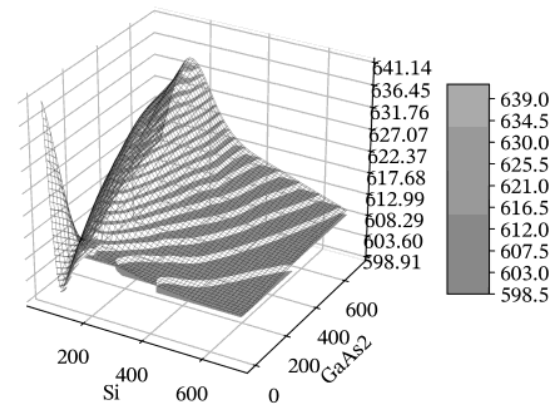

Креп. на сапфире, GaAs $=50$ мкм

\section{Лumepamypa}

[1] E. Suhir, Y.C. Lee, C.P. Wong, A.C. Pliska, C. Bosshard. Micro- and Opto- Electronic Materials and Structures: Physics, Mechanics, Design, Reliability, Packaging. Volume I. 2007 Springer Science+Business Media, Inc., ISBN 978-0-387-27974-9, p.494. 